Journal of English Language Teaching and Applied Linguistics

ISSN: 2707-756X

DOI: $10.32996 /$ jeltal

Journal Homepage: www.al-kindipublisher.com/index.php/jeltal

JELTAL

\title{
Designing Online English Grammar Exercises 10th Graders via Learning Management System Chamilo
}

\author{
Nguyen Thi Hong Minh ${ }^{1}$ \& $\triangle$ and Truong Thuy Linh ${ }^{2}$ \& \\ ${ }^{12}$ Faculty of Foreign Languages Education, Thai Nguyen University of Education, Viet Nam \\ $\triangle$ Corresponding Author: Nguyen Thi Hong Minh, E-mail: minhnth@tnue.edu.vn
}

\author{
ARTICLE INFORMATION \\ Received: April 18, 2021 \\ Accepted: May 05, 2021 \\ Volume: 3 \\ Issue: 5 \\ DOI: $10.32996 /$ jeltal.2021.3.5.6
}

\section{KEYWORDS}

Learning management system, Chamilo, online grammar exercises, English grammar learning, online learning

\section{ABSTRACT}

The integration and application of Information Communication Technology in language teaching has become more and more prevalent in the era of 4.0, which has brought about a lot of significant influences on students' language learning. However, having a self-led online tool which is appropriate to one's students' backgrounds and is free and open-access in a school in a mountainous area in a developing country like Vietnam has not yet been so popular. In the present study, for the purpose of enhancing students' learning, online grammar exercises for 10th graders at Thai Nguyen High School, Thai Nguyen province, Vietnam, were designed in a learning management system called Chamilo. The study investigated the benefits of the platform towards students' grammar learning achievements by identifying the changes in students' scores as well as sought evaluative feedback from teachers and students as the users of the tool. The research instruments included a grammar test in the pre-intervention and after-intervention combined with two questionnaires for eight teachers and twenty students at grade 10 and interviews with the focus group of 5 students. The findings suggested a remarkable improvement in students' post-test score and a significant relationship between the practice of online exercises and students' grammar results. Furthermore, positive responses from the teachers and students on such use of the platform indicated that Chamilo could be used as learning tools to enhance students' grammar learning.

\section{Introduction}

Thanks to the continuous development of science and technology, humans now have various forms of learning. Students can study in traditional methods such as going to school, listening to the teacher, and then taking notes and studying online. Elearning has been becoming increasingly popular thanks to considerable benefits to learners. First, many people prefer online learning because of its convenience and flexibility. Learners can choose courses that suit their busy schedules. As long as they have an internet connection, they can study wherever they want, such as their private room, a public library, or a cafe. Students are never afraid of being punished for being late. In fact, online learning becomes an indispensable tool of modern education and proves its usefulness when an epidemic or natural disaster occurs. For instance, in the case of the COVID-19 pandemic, when the total closure of schools in some countries is impacting over $60 \%$ of the student population (UNESCO, 2020), distance learning has become a helpful alternative and probably continues to be more advantageous for education in the future. Together with other digital tools, learning management systems have become an essential component supporting the availability, flexibility and interactivity of distance learning. In the long list of learning management systems (LMSs) available now, such as Moodle, Edmodo, Docedo, Blackboard, Schoology, and Chamilo, Kraleva and Kralev (2019) suggest that NEO MS and Chamilo be the two LMSs that meet all the demand of educational use including learning skill tools, communication tool, and productivity tool. It is founded that Chamilo is an open resource and easy to install; thus, it can be more friendly to student users, especially to those who are not much familiar with the application of LMSs in their learning.

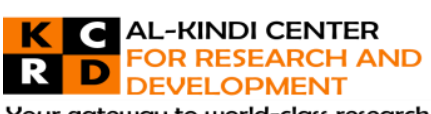

Your gateway to world-class research

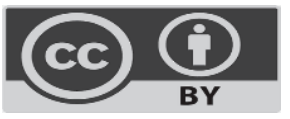

Published by Al-Kindi Center for Research and Development, United Kingdom. Copyright (c) the author(s). This open access article is distributed under a Creative Commons Attribution (CC-BY) 4.0 license 
In Vietnam, prior to COVID-19 lockdown, e-learning seemed not to be very practical in school education though it has been in practice in higher education and private educational sectors. Therefore, in such schools as Thai Nguyen High School (an affiliated school of the Thai Nguyen University of Education in the north of Vietnam), students can be quite familiar with the internet via social network but still new to the learning management system reality. With the purpose to support students' English learning without interfering with their busy schedules, in this study, a series of grammar exercises have been designed on Chamilo as a supplementary resource for $10^{\text {th }}$ graders at Thai Nguyen High School.

\section{Literature Review}

\subsection{ICT application in English teaching and learning}

The benefits of ICT have much been discussed in the literature on education in general and language teaching in particular. Fu (2013) has analyzed and summarized the following advantages of ICT in education:

- Assist students in accessing digital information efficiently and effectively

- Support student-centered and self-directed learning

- Produce a creative learning environment

- Promote collaborative learning in a distance-learning environment

- Offer more opportunities to develop critical (higher-order) thinking skills

- Improve teaching and learning quality

- Support teaching by facilitating access to course content

ICT has brought benefits to both teachers and students in language learning. More specifically, Azmi (2017) proved that ICT enhances motivation and engagement in the language classroom by stating research by Kassim et al. (2007) where they pointed out that ICT enhances meaningful interaction, boosts students' interest and motivation and ensures more participation and engagement in the classroom through the provision of authentic up-to-date materials and the appropriate skills to approach this resource. Technology integration in language classes offers students opportunities to structure communication and support collecting and sharing knowledge (Dennis et al., 2001) in instant exchanges between peers and students and teachers through various communication channels. Therefore, interactivity and communication are promoted, leading to more engagement, greater interests and motivation in the learning process. Many authors have mentioned other benefits are the promotion of discovery learning and the increase of students' autonomy and centeredness in their language learning (Lan, 2018; Lee, 2005; Murray et al., 2005). Furthermore, students' creativity can be optimized thanks to ICT. They may discover new multimedia tools and create materials in the styles readily available to them through games (Gee 2007), CDs, and television enhanced with the application though there may be some fears that online learning may reduce face-to-face interaction which tends to be more developed in traditional classes (Harrington \&Loffredo, 2010; Johnson et al., 2008). Last but not least, it is the increase in teachers' autonomy and students' independence that should be mentioned as one of the greatest advantages of ICT in language education. According to Serhan (2009), ICT boosts educators' autonomy by allowing them to create their own materials, thus providing more control over course content than in a traditional classroom setting. ICT also allows learners to take charge of their learning: they can decide their own time and place for learning; they are given authority to complete certain tasks with peers or in groups. In this way, they become more capable of working by themselves and others.

\subsection{Chamilo Learning Management System}

Chamilo, often referred to as a learning management system, is free software, providing e-learning and collaboration. It is described as a kind of software platform designed to facilitate the management and delivery of courses and monitor students' progress.

According to Jean-Marie Maes (2010), Chamilo is organized as a non-profit association according to Belgian law. The association brings together all stakeholders involved: companies as well as universities and other educational institutes, either as developing partners or as users. Chamilo focuses on building e-learning portals easily, quickly and has attractive interfaces (F. Astriawati and Djukri, 2019). Chamilo is included in the 10 best open sources of LMS and takes place in the first rank in the course of development features, collaboration features, and instruction methods. Chamilo also takes place in the second rank in the administration features instead of the other open sources of LMS such as Moodle, LRN, eFront, Dokeos, Sakai, Latitude Learning, Canvas, OLAT, and Totara.

Jean-Marie Maes (2010) also stated that Chamilo allows a lifelong learning and collaboration system that is personal and can connect to formal learning environments and social software at any time. Lifelong learning will be possible as a really continuous process, without any loss of information at any stage. The system will be flexible enough to be usable from primary school to various forms of adult education and to different working environments. 
Though Chamilo virtual platform, educators employ various teaching strategies that enhance pedagogical practice by «broadening and inviting the professor to use these strategies, which mediate the curricular contents and the way to approach them with the student in the classroom, recognizing that the integration of ICT in the teaching and learning process, without a doubt, facilitates the learning process. » (Valencia, et al., 2017).

In the field of language teaching, Rahmah et al. (2020) concluded that Chamilo is effective in teaching reading comprehension of recount texts to students with good and poor reading habits and thus the integration of virtual platforms as a teaching and learning strategy becomes a very significant tool in the learning process. Another research by Diego Torres-Dorantes and Salvador Bautista-Maldonado (2020) found out that Chamilo is an effective tool to increase preposition learning through the pre-test and post-test results and elementary student participants appreciate the pleasance and interactivity of the platform, and thus suggests the use of Chamilo as an alternative for teaching prepositions of place in the English language and decreases the complexity of implementing them in Spanish language students.

\section{Methodology}

\subsection{Research Questions}

The research sought to answer the following three questions :

1. How are students' grammar results improved?

2. What are students' attitudes towards the online English grammar exercises on Chamilo?

3. How do teachers evaluate the use of Chamilo for students' English grammar learning?

\subsection{Participants}

The participants of the study include twenty 10th graders at Thai Nguyen High School, an affiliated school in the Thai Nguyen University of Education, Vietnam. They are both girls and boys at the age of 16 who want to improve their English grammar as it is an indispensable part of their exams at different levels. They are all willing to take part in the project and practice online English grammar exercises on Chamilo. All the students have learnt English for at least 7 years at school as a compulsory subject. They are supposed to reach A2 level as indicated by the English national curriculum. Nevertheless, it can be inferred from our observations in the English classes that the majority is below their intended proficiency level. Therefore, even though English grammar is an essential part of their school learning as well as their exam, it seems that they are still struggling not only to complete English grammar tests with high scores but also to apply it in their English communication.

A focus group of 5 students among the twenty were also selected for in-depth interviews about their attitudes and desire to use the platform for their English learning further.

Moreover, eight school teachers were invited for their evaluative comments on the use of Chamilo exercises. They have been in the profession for more than 5 years and involved in English teaching for 10 graders for a similar length of time. Hopefully, their experience in the teaching can help provide more professional feedback on the grammar exercises design on the Chamilo platform.

\subsection{Research Design}

To begin with, a thorough examination of English textbook for 10th graders at Thai Nguyen High School was carried out for the list of grammar items introduced in the learning program. A series of exercises for such grammatical themes were designed on this basis. Then, a class for grammar learning was then created on the Chamilo learning management system for personalized use.

The intervention was conducted in 8 weeks in Thai Nguyen High School. Initially, students in grade 10 were given a brief introduction of the project and based on their willingness for participation, 20 students were selected. The participants were then asked to do the grammar pre-test; their answers were later scored and analysed. In this first week, the students are also guided to create their Chamilo account and explore the platform for familiarising the interface and functions. In the next seven weeks, the students were asked to do Chamilo grammar exercises from Unit 1 to Unit 10 in their school textbook. Finally, the participants were asked to do the post-test, questionnaire and interview, and the teachers were invited for the comments at this last point. The data from the post-test, questionnaires and interviews were analysed and discussed.

\subsection{Data collection instruments}

Two different questionnaires were designed to collect feedback from the teachers and students as users after the intervention. The first questionnaire was set up as an evaluation form about Chamilo for twenty 10th graders to collect their comments about Chamilo online English grammar exercises. The second questionnaire was to gather more professional evaluation from school teachers. The perspectives for evaluations from both teachers and students are categorized in 5 areas: design and layout, platform organization, content, communication and discussion tools, testing and assessment tools. 
Interviews with the focus group were added for more in-depth data on students' attitudes about English grammar exercises on Chamilo.

Tests were also employed as research instruments: the pre-test was to find out the English grammar proficiency of 10th graders before joining the study; the post- test sought to discover how their English grammar results were improved after taking part in the project. Each test consisted of 25 questions equivalent to the maximum score of 25 . The time allowance for the tests was 30 minutes. The tests covered the grammatical topics and items learned from Unit 1 to Unit 10 as listed below :

\begin{tabular}{|c|c|}
\hline \multirow[t]{3}{*}{ Unit 1} & The present simple \\
\hline & Adverbs of frequency \\
\hline & The past simple \\
\hline \multirow[t]{2}{*}{ Unit 2} & Wh-questions \\
\hline & Gerund and to-infinitive \\
\hline \multirow[t]{2}{*}{ Unit 3} & The past perfect \\
\hline & The past perfect vs. The past simple \\
\hline \multirow[t]{3}{*}{ Unit 4} & The + adjective \\
\hline & Used to + infinitive \\
\hline & Which as a connector \\
\hline \multirow[t]{2}{*}{ Unit 5} & The present perfect \\
\hline & $\begin{array}{l}\text { The present perfect passive } \\
\text { Who, which, that }\end{array}$ \\
\hline \multirow[t]{2}{*}{ Unit 6} & The present progressive (with a future meaning) \\
\hline & Be going to \\
\hline \multirow[t]{2}{*}{ Unit 7} & The present perfect \\
\hline & Because of and in spite of \\
\hline \multirow[t]{2}{*}{ Unit 8} & Reported speech: statements \\
\hline & Conditional sentence type 1 \\
\hline \multirow[t]{2}{*}{ Unit 9} & Should \\
\hline & Conditional sentence type 2 \\
\hline Unit 10 & The passive voice \\
\hline
\end{tabular}

Table 1. List of grammar items in English 10 Textbook

\section{Results and Discussion}

\subsection{Results}

\subsubsection{The improvement of student's performances reflected in the pre-test and post-test}

\begin{tabular}{|l|l|l|l|l|l|}
\hline $\begin{array}{l}\text { Pre-test } \\
\text { scores }\end{array}$ & Frequency & Percent & $\begin{array}{l}\text { Post-test } \\
\text { score }\end{array}$ & Frequency & Percent \\
\hline 6.00 & 4 & 20.0 & 8.00 & 3 & 15.0 \\
\hline 8.00 & 2 & 10.0 & 10.00 & 5 & 25.0 \\
\hline 9.00 & 2 & 10.0 & 12.00 & 3 & 15.0 \\
\hline 10.00 & 3 & 15.0 & 13.00 & 4 & 20.0 \\
\hline 11.00 & 2 & 10.0 & 16.00 & 1 & 5.0 \\
\hline 12.00 & 2 & 10.0 & 18.00 & 2 & 10.0 \\
\hline 15.00 & 3 & 15.0 & 20.00 & 1 & 5.0 \\
\hline 20.00 & 2 & 10.0 & 22.00 & 1 & 5.0 \\
\hline Total & 20 & 100.0 & Total & 20 & 100.0 \\
\hline
\end{tabular}

Table 2. Frequencies of students' pre-test and post-test scores

Table 2 shows the frequencies of students' pre-test and post-test scores. The lowest pre-test scores were 6.00 (out of 25.00 ), occupying $20 \%$, which was also the highest percentage in the pre-test scores. The maximum score of 20.00 accounting for $10 \%$ was one of the smallest proportions. However, there were remarkable changes in students' grammar results reflected in the post-test. The minimum score in the post-test now rose to 8.00 (while that of the pre-test was 6.00 ) with a percentage of $15 \%$. Though the number of students achieving the highest scores of and 22.00 and 22.00 after the intervention remained the same (compared with those obtaining the scores of 20.00 in the pre-test), the percentage of those who got above the average scores (ranging from 13.00 to 22.00 ) in the post-test demonstrated a considerable growth with the figure of $45 \%$ while that of the pretest took only $25 \%$. 


\begin{tabular}{|l|l|l|l|l|l|}
\hline \multicolumn{2}{|l|}{ Pre-test scores } & \multicolumn{3}{|l|}{ Post-test scores } & \\
\hline \multirow{2}{*}{$\mathrm{N}$} & Valid & 20 & $\mathrm{~N}$ & Valid & 20 \\
\cline { 2 - 3 } & Missing & 0 & & Missing & 0 \\
\hline Mean & 10.95 & Mean & 12.80 \\
\hline Minimum & 6.00 & Minimum & 8.00 \\
\hline Maximum & 20.00 & Maximum & 22.00 \\
\hline
\end{tabular}

Table 3. Descriptive statistics of pre-test and post-test on students' performances

The descriptive statistics of students' performances before and after the implementation of practicing online English grammar exercises on Chamilo was demonstrated in Table 3. It can be seen that in the pre-test the minimum score of the students' performance was 6 out of 25 (equivalent to $24 \%$ completion of the test) while the maximum was 20 (equivalent to $80 \%$ ); the mean score was 10.95 . The situation positively changed after students' participation in Chamilo as the minimum score of the students' post-test performance was 8 out of 25 (equivalent to $32 \%$ completion of the test) and the maximum was 22 (equivalent to $88 \%$ ). Accordingly, the mean score rose to 12.80 , indicating the practice of students on Chamilo is relatively beneficial to their English grammar results.

\begin{tabular}{|l|l|}
\hline Pearson Correlation & $.624^{* *}$ \\
\hline Sig. (2-tailed) & .003 \\
\hline N & 20 \\
\hline
\end{tabular}

**. Correlation is significant at the 0.01 level (2-tailed).

Table 4. The correlations of pre-test and post-test scores

The association between pre-test and post-test scores reflected in Table 4 . The $p$-value of pre-test and post-test scores of 0.003 $(<0.05)$ suggested a significant relationship between students' participation in Chamilo exercises and their grammar results. It is also noteworthy that high scores in the pre-test go with corresponding high scores in the post-test. Moreover, the r-value of 0.624 indicates a strong relationship between pre-test and post-test performance.

\subsubsection{The evaluation of students on Chamilo grammar exercises}

Table 5 displays different perspectives on students' evaluation of Chamilo grammar exercises in terms of design and layout, organization, contents, communication and discussion tools and testing and assessment tools. Generally, the grammar exercises designed on the platform received positive feedback from the participants with a mean score in the range of between 4.25 and 4.80, which indicates general agreements of the students that the platform offers well-organized presentation, adequate contents and functions. Students seemed more satisfied with the communication and discussion tools and the contents compared to other perspectives. The statements "I can see my scores as soon as I finish the exercises" and "I can see the explanation of each correct answer after I finish the exercises, so I have a better understanding" were the two ideas that most students showed their agreement, suggesting their contentment in the instant assessment and spontaneous feedback from the platform on the completion of the grammar tasks. Despite the overall positive evaluation, it appears that the participants would require more functions in Chamilo as the statement "I find that the platform has adequate functions such as documents, learning path, tests, forums, etc." was the perspective with the lowest mean score of 4.25.

\begin{tabular}{|l|l|c|c|c|c|c|}
\hline Perspectives & Statement & $\mathrm{N}$ & $\begin{array}{c}\text { Minimu } \\
\mathrm{m}\end{array}$ & Maximum & $\begin{array}{c}\text { Std. } \\
\text { Mean } \\
\text { Deviation }\end{array}$ \\
\hline Design and Layout & $\begin{array}{l}\text { I find the platform is user-friendly with a simple } \\
\text { and intuitive interface. }\end{array}$ & 20 & 3.00 & 5.00 & 4.7000 & .57124 \\
\cline { 2 - 7 } & $\begin{array}{l}\text { I only need minimal clicks to access the } \\
\text { materials. }\end{array}$ & 20 & 3.00 & 5.00 & 4.4000 & .68056 \\
\hline Organization & $\begin{array}{l}\text { find that the platform has adequate functions } \\
\text { such as documents, learning path, tests, forums, } \\
\text { etc. }\end{array}$ & 20 & 3.00 & 5.00 & 4.2500 & .78640 \\
\hline
\end{tabular}




\begin{tabular}{|l|l|c|c|c|c|c|}
\hline Contents & $\begin{array}{l}\text { I find that the platform can cover all grammar } \\
\text { items in the English 10th textbook. }\end{array}$ & 20 & 3.00 & 5.00 & 4.3000 & .86450 \\
\cline { 2 - 7 } & $\begin{array}{l}\text { I can see the correct answers after I finish each } \\
\text { exercise to know where I made the mistakes. }\end{array}$ & 20 & 3.00 & 5.00 & 4.6500 & .67082 \\
\cline { 2 - 7 } & $\begin{array}{l}\text { I can see the explanation of each correct answer } \\
\text { after I finish the exercises, so I have a better } \\
\text { understanding. }\end{array}$ & 20 & 3.00 & 5.00 & 4.8000 & .52315 \\
\hline $\begin{array}{l}\text { Communication and } \\
\text { Discussion Tools }\end{array}$ & $\begin{array}{l}\text { I can use the communication with my teacher } \\
\text { and my friends via Forums, Dropbox. }\end{array}$ & 20 & 3.00 & 5.00 & 4.4500 & .82558 \\
\hline $\begin{array}{l}\text { Testing and } \\
\text { assessment tools }\end{array}$ & $\begin{array}{l}\text { I can see my scores as soon as I finish the } \\
\text { exercises. }\end{array}$ & 20 & 3.00 & 5.00 & 4.8000 & .52315 \\
\cline { 2 - 7 } & $\begin{array}{l}\text { I find that the platform provides data storage } \\
\text { system so I can observe my learning progress. }\end{array}$ & 20 & 3.00 & 5.00 & 4.4000 & .75394 \\
\hline & Valid N (listwise) & 20 & & & & \\
\hline
\end{tabular}

Table 5. Students' evaluation perspectives

Furthermore, interviews among the focus group revealed similar results. The participants mostly appreciated their participation in Chamilo platform for their grammar practice. The following quotes from the focus group interviews indicated significant changes in students' grammar learning.

"I'm happy with the exercises. They are in parallel with the grammar items I have to learn in my English course," Student A, female.

"After practicing online English exercises on Chamilo, I can do some kinds of exercises that I cannot do before. For example, I can distinguish between the past simple and the past perfect because I have repeated exercises of the same kind many times," Student B, male.

"I also find I learn English grammar better than before. I do not get confused among conditional sentences type 1,2,3 anymore. My English teacher also praised me when I can do the tasks at school," Student C, male.

Obviously, the practice of grammar items on Chamilo has helped students' grammar learning thanks to its relevance to the students' in-class learning program, the abundance of exercises, and opportunities for repetitive practice and attempts. Moreover, the accordingly positive responses from the teachers on students' fulfilment of grammar tasks have demonstrated good effects on students; for example, student $\mathrm{C}$ mentioned his teacher's compliment for his progress. It can also be seen that the participants have made improvements in their grammar results, which were shown in their capacity to distinguish some confusing grammar items as in student B and student C's quoted lines.

For a deeper understanding of students' evaluation, their expectations are mentioned in the discussions with the focus group. The interviewees all expressed their desire to continue their practice of English grammar exercises on Chamilo. The reasons for this wish come from the practicality of the platform in preparing the students for different school exams as well as the realization of the importance of grammar on English language learning and testing.

"I want to continue to do exercises on Chamilo because I want to improve my English grammar exercises. Grammar is an indispensable part of my end-of-term and the national high school exams," Student D, male.

Another student was more practical when mentioning the benefits of such a platform as Chamilo in reducing the cost: "Of course I want to continue to learn grammar on Chamilo, because I can reduce costs of buying books and printing documents," student $\mathrm{E}$, female. This wise choice should be considered in the context of 4.0, when E-learning has become more and more popular and, in some cases, has replaced traditional learning.

\subsubsection{The evaluation of teachers on Chamilo grammar exercises}

Teachers' evaluations about online English grammar exercises were also collected in design and layout, Platform organization, Contents, Communication and Discussion tools, and Testing and assessment tools. The judgments are presented in Table 6 as follows. 


\begin{tabular}{|c|c|c|c|c|c|c|}
\hline Perspectives & Statement & $\mathrm{N}$ & $\underset{\mathrm{m}}{\text { Minimu }}$ & Maximum & Mean & $\begin{array}{l}\text { Std. } \\
\text { Deviation }\end{array}$ \\
\hline Design and Layout & $\begin{array}{l}\text { The system is user-friendly with simple, intuitive } \\
\text { interface and minimal clicks to access materials. }\end{array}$ & 8 & 4.00 & 5.00 & 4.8750 & .35355 \\
\hline \multirow[t]{2}{*}{ Organization } & $\begin{array}{l}\text { The platform has adequate functions such as: } \\
\text { course description, documents, learning path, } \\
\text { tests, forums, etc. }\end{array}$ & 8 & 4.00 & 5.00 & 4.6250 & .51755 \\
\hline & $\begin{array}{l}\text { The organization of the platform is flexible (the } \\
\text { teachers can change the name and the order of } \\
\text { each function and hide the function which is } \\
\text { not suitable for their courses). }\end{array}$ & 8 & 4.00 & 5.00 & 4.2500 & .46291 \\
\hline \multirow[t]{3}{*}{ Contents } & $\begin{array}{l}\text { The platform covers all grammar items in the } \\
\text { English 10th textbook. }\end{array}$ & 8 & 4.00 & 5.00 & 4.2500 & .46291 \\
\hline & $\begin{array}{l}\text { Many kinds of exercises such as multiple } \\
\text { choices, True/Fal exercise, gap-filling, etc are } \\
\text { available for students. }\end{array}$ & 8 & 4.00 & 5.00 & 4.5000 & .53452 \\
\hline & $\begin{array}{l}\text { The teacher can add explanations for each } \\
\text { correct answer to help students have better } \\
\text { understanding. }\end{array}$ & 8 & 4.00 & 5.00 & 4.5000 & .53452 \\
\hline $\begin{array}{l}\text { Communication and } \\
\text { Discussion Tools }\end{array}$ & $\begin{array}{l}\text { The platform has available communication and } \\
\text { discussion tools for teacher and students' } \\
\text { interaction such as Forums, Dropbox. }\end{array}$ & 8 & 4.00 & 5.00 & 4.3750 & .51755 \\
\hline \multirow[t]{4}{*}{$\begin{array}{l}\text { Testing and } \\
\text { assessment tools }\end{array}$} & $\begin{array}{l}\text { The platform offers the automatic grading } \\
\text { function. }\end{array}$ & 8 & 4.00 & 5.00 & 4.7500 & .46291 \\
\hline & $\begin{array}{l}\text { The platform provides a data storage system } \\
\text { for both teachers and students to observe the } \\
\text { learning progress. }\end{array}$ & 8 & 4.00 & 5.00 & 4.6250 & .51755 \\
\hline & $\begin{array}{l}\text { The platform provides the data report function } \\
\text { for both teachers and students to print or make } \\
\text { reports. }\end{array}$ & 8 & 4.00 & 5.00 & 4.1250 & .35355 \\
\hline & Valid N (listwise) & 8 & & & & \\
\hline
\end{tabular}

Table 6. Teachers' evaluation perspectives

Overall, the teachers had positive observations on Chamilo grammar exercises, which were similarly reflected in those of the students with the mean score of all items at over 4.000. The design and layout of the platform noticeably received the most constructive feedback from the teachers with the mean score of 4.875 and standard deviation of 0.35355: they appreciated the user-friendliness, simple, intuitive interface and convenient access to materials. Furthermore, the testing and assessment tools continued to be one of the most beneficial functions as agreed by the respondents, showing in the mean score of 4.750 and 4.625 for the automatic grading function and storage system, respectively.

\subsection{Discussion}

The following discussion is provided in light of the students' test results, the questionnaires and the focus group interview on the students' participation in the practice of Chamilo grammar exercises.

First of all, the mean score of 10.95 (out of 25.00) in the pre-test indicates that the majority of $10^{\text {th }}$ graders in Thai Nguyen High School have fairly poor grammar knowledge, which definitely affects their academic achievements negatively as in English exam papers, grammar directly or indirectly accounts for $40 \%$ of the total score. More seriously, weak understandings of grammar may 
prevent students from receiving the language inputs as well as block them from producing the language effectively. As a consequence, inefficient communication in the target language and the loss of interest in the learning of the language will be something of anticipation. That pre-test score should evoke thoughtful considerations of the administrators, teachers and students on English grammar teaching and learning at the school. Further studies on the causes and factors affecting the issue should be investigated, and solutions to more quality, effective teaching and learning should be addressed.

Secondly, the improvement in students' score after the intervention suggests the application of such learning management systems as Chamilo in English grammar learning in particular and other subjects in general in Thai Nguyen High School and other educational institutions with similar conditions. Furthermore, the appraisal of both the teachers and students collected from the questionnaires and the interviews indicates the benefits of the online practice of grammar towards the learning results, in which the betterment of the scores is just one issue while other advantages including reduction of cost, flexibility, track record on students' progress, feedback and explanation on students' tasks should be of concerns as well. Nevertheless, shortcomings of the platform should be seriously examined to be overcome for more sustainable use of the platform and better benefits toward students' English learning.

Designing Chamilo grammar exercises indeed is the first attempt to integrate ICT into English learning and teaching in Thai Nguyen High School. For more frequent and official use of such learning management systems, it is advisable that further studies on their effectiveness on different dimensions should be conducted and different stakeholders' feedback should be collected at a broader range.

\section{Conclusion}

The study has aimed to enhance students' grammar learning in a high school in Thai Nguyen Province, Vietnam, through the use of online exercises designed in Chamilo learning management system. The findings of the research can be summarized as follows. First, the study has pointed out significant improvements in students' grammar scores after taking part in the practice of grammar on the Chamilo platform. The finding is accordant to the conclusion in research of F. Astriawati and Djukri (2019) because e-learning shows effectiveness in enhancing students' intended skills. Second, teachers and students as users have expressed positive evaluation of the English grammar designed on this platform. This promising result indicates the advantages of this mentioned learning management system towards students' grammar learning and thus suggested applying and integrating such online tools in English learning. The present study may inform school administrators and teachers in countries like Vietnam of the potential and practicality of new e-learning tools for English learning in particular and education in general. However, more uses of Chamilo platform, for instance, forums and feedback, are required to be explored and applied for English learning, and other benefits for different stakeholders should be investigated and further discussed. Therefore, further studies on the issue are recommended and more serious considerations at a large scale should be required to sustain such benefits.

Funding: This research received no external funding.

Acknowledgements: We would like to express our sincere gratitude towards the Thai Nguyen University of Education and Thai Nguyen High School for allowing us to conduct the study. Our greatest thanks also go to the twenty 10th graders at Thai Nguyen High School who were willing to participate in the project either as the participants or the respondents of the questionnaires and the interviewees in the focus group. Last but not the least, we would like to acknowledge the teachers' responses to the questionnaire as well as their helpful suggestions and feedback upon the completion of the research.

Conflicts of Interest: The authors declare no conflict of interest. The funders had no role in the design of the study; in the collection, analyses, or interpretation of data; in the writing of the manuscript, or in the decision to publish the results.

\section{References}

[1] Azmi, N. (2017). The Benefits of Using ICT in the EFL Classroom: From Perceived Utility to Potential Challenges, Journal of Educational and Social Research, 7(1), p.111-118. Doi:10.5901/jesr.2017.v7n1p111

[2] Dennis, A. R., Wixom, B. H., \& Vandenberg, R. J. (2001). Understanding fit and appropriation effects in group support systems via metaanalysis, MIS Quarterly, 25(2). URL: https://doi.org/10.2307/3250928

[3] Astriawati, F. \& Djukri. (2019). Developing Chamilo-Based E-Learning in Environmental Change Material to Enhance Students' Scientific Literacy Skills, Journal of Physics: Conference Series. doi:10.1088/1742-6596/1397/1/012049

[4] Fu, J. S. (2013). ICT in Education: A Critical Literature Review and Its Implications, International Journal of Education and Development using Information and Communication Technology (IJEDICT), 9(1), 112-125.

[5] Gee, J. P (2007). What video games have to teach us about learning and literacy. New York: Palgrave.

[6] Harrington, R., \& Loffredo, D. A. (2010). MBTI personality type and other factors thatrelate to preference for online versus face-to-face instruction, The Internet and Higher Education, 13, 89-95.

[7] Johnson, R. D., Hornik, S., \& Salas, E. (2008). An empirical examination of factors contributing to the creation of successful e-learning environments, International Journal of Human Computer Studies, 66, p.356-369.

[8] Kraleva, R. and Kralev, V. (2019). An Analysis of Some Learning Management Systems, International Journal on Advanced Science Engineering and Information Technology, 9(4), p.1190-1198. 
[9] Lan, Y. (2018). Technology enhanced learner ownership and learner autonomy through creation, Educational Technology Research and Development, 66, p.859-862. Retried from https://link.springer.com/article/10.1007/s11423-018-9608-8

[10] Lee, C. (2005). Web-based Teaching and English Language Teaching: A Hong Kong Experience. Hong Kong: The Chinese University Press of Hong Kong.

[11] Maes, J. (2010). A Second Generation Open Source E-learning and Collaboration Platform, International Journal of Advanced Corporate Learning, 3(3). doi:10.3991/ijac.v3i3.1364

[12] Murray, D. E., et al (2005). Information technology and innovation in language education. In Davison, C. (E.d.) Hong Kong: Hong Kong University Press.

[13] Rahmah, S., N. (2020). Edmodo and Chamilo Media in Know - Want - Learned Strategy to Teach Reading Comprehension of Recount Texts to Students with Different Reading Habits, English Education Journal, 10(1), p.37-45. Retrieved from http://journal.unnes.ac.id/sju/index.php/eej

[14] Serhan, D. (2009). Preparing preservice teachers for computer technology integration, International Journal of Instructional Media, 36 p.439-447.

[15] Torres-Dorantes, T. \& Bautista-Maldonado, S. (2020). Chamilo un recurso pedagógico para la ense-ñanza de las preposiciones de lugar en el idioma inglés. In book: Tecnología Innovación y Práctica Educativa Publisher: CIATA.org-UCLM, p.52-60. Retrieved from: https://www.researchgate.net/profile/Manuel-Prieto5/publication/343040982_Tecnologia_Innovacion_y_Practica_Educativa/links/5f12c66ea6fdcc3ed71212b6/Tecnologia-Innovacion-yPractica-Educativa.pdf\#page $=75$

[16] UNESCO,(2020). What have we learnt: Overview of findings from a survey of ministries of education on national responses to COVID-19. Retrieved from http://uis.unesco.org/sites/default/files/documents/national-education-responses-to-covid-19-web-final en 0.pdf

[17] Valencia, H., G., et. al. (2017). Strategies Used by Professors through Virtual Educational Platforms in Face-To-Face Classes: A View from the Chamilo Platform, English Language Teaching, 10(8). URL: http://doi.org/10.5539/elt.v10n8p1 